\title{
China Land Circulation Reviews
}

\author{
Xia Tong and Shenrong Gao* \\ Nantong University, PR China
}

Submission: February 17, 2017; Published: March 27, 2017

"Corresponding author: Shenrong Gao, Nantong University, School of Business, Nantong, Jiangsu, 226001, PR China, Tel: +86-13921601072; Fax: +86-513-85355968; Email: tongxiagao@126.com

\section{Mini Review}

The development of agriculture economy has become the hot topic in the whole world. The paper empirically analyses agriculture economic development status in china. In China, the basic units that agricultural products are the scattered farmers, of which the essential characteristic is the small scale production. Comparing the land utilization condition between scattered farmers and large-scale farms in Ethiopia, Stein concludes that the land cost is so low in this country that the labor productivity of farms is higher that of scattered farmers. Wang Xiuqing argues that land integration can achieve the scale operation of agricultural products and improve farmers' production gain. According to li Meiye, the improvement of production gain and increase of farmers' income can be both realized by largescale cultivation of agricultural products through relocation of elements. In China, the small production scale and low efficiency of scattered farmers cannot meet the needs of markets for means of production and agricultural products. The reasons are as follows. First of all, their small-scale production is not wellorganized. The market information asymmetry and unblocked market channels also lead to their disadvantage situation in the price game. They can hardly be the main part of modern agricultural market. In addition, the variety of production from scattered farmers is not enough and the quality of it is not guaranteed that cannot meet the need of mass wholesale market. So both the previous study and the current situation in China have proved that the production mode of scattered farmers is not helpful to the development of agricultural production. Most scholars argue that agricultural large-scale production is imperative in the transition of production mode.
Through the calculation of Cobb-Douglas production function in Jiangsu and Zhejiang province, their optimal land circulation scale is much larger than the current average cultivation scale. The production of agricultural products has the characteristics of increasing returns to scale. The use efficiency of labor force element and land element is comparatively low and the allocative efficiency has not reached the Pareto Optimality. The optimal allocation of resources needs to be achieved by land circulation. Therefore, land circulation should be encouraged and supported to make full use of land resources. Some places in Jiangsu and Zhejiang province are carrying out fertile farmland of a large area which enlarges the scale of land circulation. When the benefit caused by land circulation equals the circulation cost, the land will gradually achieve the optimal production scale.

So the government should establish laws and regularities. There must be laws to go by and the laws must be observed and strictly enforced in the process of land circulation. The construction of farmland, road transport and water conservancy should be strengthened and the ability to provide auxiliary items for electrified and mechanized equipment should be improved. The publicity and guidance to farmers should be enhanced and their enthusiasm to be involved in land circulation should be motivated.

In a word, China must take actions to positively accept this challenge as soon as possible, the production of agricultural products features is increasing returns to scale and the government should establish the laws to help land circulation. 
This work is licensed under Creative Commons Attribution 4.0 License

DOI: 10.19080/ARTOAJ.2017.04.555662
Your next submission with Juniper Publishers will reach you the below assets

- Quality Editorial service

- Swift Peer Review

- Reprints availability

- E-prints Service

- Manuscript Podcast for convenient understanding

- Global attainment for your research

- Manuscript accessibility in different formats ( Pdf, E-pub, Full Text, Audio)

- Unceasing customer service

Track the below URL for one-step submission https://juniperpublishers.com/online-submission.php 